\title{
Grazing management systems and their effects on savanna ecosystem dynamics: A review
}

\author{
Olaotswe Ernest Kgosikoma $^{1,2 \star}$, Witness Mojeremane ${ }^{3}$ and Barbra A. Harvie ${ }^{1}$ \\ ${ }^{1}$ University of Edinburgh, Crew Building, West Mains Road, EH9 3JN, Scotland. \\ ${ }^{2}$ Department of Agricultural Research, Private Bag 0033, Gaborone, Botswana. \\ ${ }^{3}$ Botswana College of Agriculture, Private Bag 0027, Gaborone, Botswana.
}

Accepted 14 May, 2013

\begin{abstract}
The savanna ecosystems support livestock production and livelihood of pastoral communities. The degradation of savanna ecosystems due to overgrazing had lead government commercializing communal grazing land to privately owned ranches. However, grazing policies in Southern Africa had recently been debated, and yet there are few studies comparing grazing management systems on ecological system. This article provides an overview of current knowledge on effect of grazing management systems on savanna ecosystems. Ranching and communal grazing do not necessarily affect soil, herbaceous and woody vegetation differently. Thus current management systems do not promote sustainability of savanna ecosystems and there is a need for further research and participation of local communities on addressing land degradation.
\end{abstract}

Key words: Fencing policy, rangeland degradation, sustainability, livestock production.

\section{INTRODUCTION}

Globally, managed grazing lands comprises the largest land use (Liebig et al., 2006) estimated to cover about $25 \%$ of Earth's land surface (Asner et al., 2004). The extensive area covered by rangelands makes them an essential resource for maintaining biodiversity ( $\mathrm{O}^{\prime}$ Connor, 2005) and a source of livelihood, especially for rural communities (Eriksen and Watson, 2009a; Muhumuza and Byarugaba, 2009). They are utilised for livestock production which has continually played a significant role in the economic development of rural communities world-wide. It is estimated that approximately $76 \%$ of Botswana's total land surface area is used for grazing by both domestic and wild animals (Asner et al., 2004). Thus, grazing land, especially communal rangelands, are being degraded due to overgrazing which threaten their sustainability (Vetter, 2005; Darkoh, 2009) and rural communities whose livelihoods depends on livestock rearing.
The savanna ecosystems are highly dynamic, characterized by erratic rainfall and high rate of vegetation dynamics (Herlocker, 1999; Dahdough-Guebas et al., 2002), soil nutrient levels, fire and herbivory (Sharpe, 1992). But, livestock management systems can exert a considerable change on the diversity, composition, structure, and development of native plant communities (Popolizio et al., 1994; Vavra et al., 2007) in rangelands. Most savannas are degraded and dominated by unpalatable and annual herbaceous plant species and encroached by woody plants (van Vegten, 1984; Abule et al., 2005). The changes in the composition of plant species in savanna ecosystems has a significant influence on the sustainability of livestock production (Sankaran et al., 2005). Proper understanding of effects of grazing management systems on savanna ecosystem dynamics is therefore essential in maintaining productivity and biodiversity (Sternberg et al., 2000; 
Mohammed and Bekele, 2010). The objective of this paper is to synthesis existing knowledge on grazing management systems and their effects on savanna ecosystem.

\section{GRAZING MANAGEMENT SYSTEMS AND RELATED POLICY}

Grazing management systems refer to all production systems that are used to exploit the rangeland through grazing. Savanna systems have been used for many centuries extensively for grazing livestock, with communal grazing land and commercial ranching being the dominant land use management systems (Rohde et al., 2006; Masike and Urich, 2008; Terefa, 2011). In southern Africa, the communal grazing rangelands are located in tribal land and shared by all pastoral farmers (Rohde et al., 2006; Masike and Urich, 2008). The communal grazing system used to be mainly dominated by subsistence farmers, but has shifted towards a cash economy (Wigley et al., 2010) in recent years.

Livestock management in communal grazing land is mainly influenced by local ecological knowledge (Smet and Ward, 2005). Mixed livestock, dominated by cattle and goats, is the traditional practices in the communal grazing system (Wigley et al., 2010). Livestock herding used to be a key part of managing communal rangelands which was based on mobility, splitting and dispersing livestock over the landscape during the wet and dry seasons (Oba et al., 2000), to ensure limited dry concentrated continuous grazing (Kioko et al., 2012). However, with recent developments in some developing countries (for example, Botswana), herding is no longer a common livestock management practice (Reed et al., 2008), instead livestock is allowed to continuously and selectively graze without any control (Parsons et al., 1997) around water sources such as boreholes. Borehole rights provided by land authorities such as Land Boards in Botswana indirectly give the borehole owners control of grazing resources around the water points.

The communal rangelands are used for grazing throughout the year (Oba et al., 2001) by pastoral communities without paying any levy associated with livestock grazing (Weimer, 1977). Consequently, several studies have suggested that they are poorly managed and degraded (Ellis and Swift, 1988; Abel, 1997; Dougill et al., 1999; Hendricks et al., 2007). As illustrated by "Tragedy of Commons" (Hardin, 1968), it is argued that each pastoralist find it profitable to increase his herd size in communal rangeland. However, as pastoralists increases their herd size, the livestock density increases to exceed the rangeland's carrying capacity resulting in overgrazing and land degradation (van Vegten, 1984). Several countries have introduced policies and laws in response to land degradation due to poor management of communal rangelands. In Botswana, the government introduced commercial ranches through the Tribal
Grazing Land Policy (TGLP) (Botswana Government, 1975). The communal grazing land was demarcated into ranches owned by individuals or a group of farmers who paid a levy for exclusive use of fenced ranches (Dougill et al., 1999). According to the TGLP (1995) and Tsimako (1991), the TGLP served the following purposes:

a) To control overgrazing and reduce land degradation through improved rangeland management such as rotational grazing and optimal stocking rates in commercial ranches and shifting large herds of livestock from already overstocked communal lands.

b) To improve livestock productivity and farmers' income through better management practices (for example, controlled breeding and early weaning).

c) To secure interest of the poor (social equity) by reserving the communal grazing land for small scale farmers and have reserve land for future generations.

The management of commercial ranches is based on a range-succession model, whereby the goal of management aligns stocking rates to the carrying capacity of ranches (Mphinyane et al., 2008). Commercial ranches are characterised by rotational grazing which, consist of alternating periods of use and rest, to promote vegetation growth. To facilitate rotational grazing, several paddocks are demarcated within ranches to spread the livestock grazing intensity uniformly across the rangeland. The main focus in commercial ranches is on cattle rearing (Smet and Ward, 2005). Ranches have been promoted as a sustainable livestock management system by policies in Southern Africa (TGLP, 1975; Tsimako, 1991; Rohde et al., 2006), although they have high costs associated with fencing, drilling and water reticulation (Motlopi, 2006). Commercial livestock ranches are suitable for farmers with adequate financial resources. Their establishment has marginalised poor pastoral farmers because the total area for animal production in communal grazing land has declined dramatically in recent years (Eriksen and Watson, 2009b). This is further exacerbated by dual grazing rights which allow farmers allocated ranches to continue grazing their livestock in communal rangelands (Thomas and Sporton, 1997).

Several studies have criticised the conversion of communal rangelands to commercial livestock ranches (Abel, 1997; Rohde et al., 2006). Abel (1997) indicated that fencing policy is based on wrong assumptions and subsequently has failed to reduce rangeland degradation (Dahlberg, 2000). The productivity and sustainability of communal rangelands and their contribution to the livestock industry is also being underestimated (Abel, 1997). The communal grazing system is suitable for aridland ecosystems because it is adapted to rainfall variability and spatial heterogeneity through opportunistic management such as mobility (Westoby et al., 1989). The TGLP had a provision protecting the interests of the poor pastoral farmers through reserve areas and removal of farmers with large herd from the communal rangeland 
(Weimer, 1977). However, it was not clearly documented how this was to be achieved, given the fact that communal rangelands continue to shrink as more ranches are being demarcated.

The appropriateness of commercial livestock ranches in dry savannas has been debated in recent years (Ellis and Swift, 1988; Dahlberg, 2000; Rohde et al., 2006). Processes in savanna ecosystems are primarily influenced by rainfall variability and thus suited to traditional practices in communal land (Ellis and Swift, 1988; Westoby et al., 1989). Yet, few studies have been conducted to compare the effects of livestock grazing management systems of savanna ecosystems dynamics (Dahlberg, 2000; Smet and Ward, 2005; Tefera et al., 2010). Most of these studies are site specific (Asner et al., 2004), despite the high variability of the savanna ecosystem. A broad-scale multivariate analysis of relationships between diversity, environmental variables and management systems are required to understand savanna ecosystem dynamics (van der Heijden and Phillips, 2009). Analysis of interactions between natural factors (for example, rainfall and soil type) and anthropogenic drivers (Scholes and Archer, 1997) may improve our understanding of how a particular factor influences vegetation conditions (Groffman et al., 2007) in arid-land ecosystem.

\section{EFFECT OF LIVESTOCK GRAZING MANAGEMENT SYSTEMS ON SOIL HEALTH}

Soils with good physical and chemical characteristics are essential in maintaining productivity in terrestrial ecosystems and driving processes that maintain environmental quality (Moussa et al., 2008) and sustainability (Hopmans et al., 2005; Liebig et al., 2006). The biological, physical, and chemical properties of soil can be modified by livestock grazing. It has been demonstrated that intensive livestock grazing profoundly affects soils as it increases soil compaction, soil erosion and loss, decreases soil organic matter, affect nutrient cycling and reduces water infiltration (Kauffman and Kruger, 1984; Stephenson and Veigel, 1987; Fleischer, 1994; Belsky and Blumenthal, 1997; Ingram et al., 2008). Livestock grazing cause disturbances to surface soils and can influence savanna ecosystem productivity and fertility by altering the soil physical and chemical properties and thus cause land degradation (Neff et al., 2005; Liebig et al., 2006).

Livestock grazing compacts soil particularly under high grazing intensity (Fleischer, 1994; Kauffman and Krueger, 1984; Robertson, 1996; Asner et al., 2004; Fatunbi and Dube, 2008). Most studies have reported significant increases in bulk density in grazing land, especially in finer textured soils and in the soil surface layers (Warren et al., 1986; Abdel-Magid et al., 1987; Steffens et al., 2008; du Toit et al., 2009), caused by hoof traffic of livestock (Walker and Desanker, 2004). Compaction is directly related to soil productivity (Liebig et al., 2006) because it reduces water and air movement into and through the soil, and therefore reduces water availability to plant roots, restricts and reduces soil microorganisms, reduces soil nutrient availability and increase soil surface runoff and soil erosion (Fleischer, 1994; Kauffman and Krueger, 1984; Robertson, 1996; Asner et al., 2004; Fatunbi and Dube, 2008).

The soil surface erosion has profound effects on soil productivity and the ecosystem function because microorganisms, organic matter, soil fauna and roots are all concentrated in the surface soil (Brandy and Weil, 2007). Research has shown that soil erosion increases with livestock grazing intensity (Bari et al., 1995; Belsky and Blumenthal, 1997). Studies conducted in grazing land and ungrazed enclosures have reported significantly higher sediments production rates in many plant communities under grazing land (Bohn and Buckhouse, 1985; Pluhar et al., 1987), and production was observed to be significantly related to grazing intensity (Beeskow et al., 1995; Bari et al., 1995; Warren et al., 1986).

Heavy grazing reduces vegetation cover and limit organic matter inputs into the soil, and subsequently affect soil structure stability, resistance to rainfall impact, infiltration rate and soil microbial activity (Roose and Barthes, 2001; Snyman and du Preez, 2005). Overgrazing caused by livestock grazing reduces plant biomass accumulation and cause a shift in plant species composition (Owen-Smith, 1999; Klumpp et al., 2009) by replacing highly palatable grass species with their unpalatable counterparts (Owen-Smith, 1999). The shift in species composition can affect soil fertility (Scholes, 1990) because of changes in root biomass (Klumpp et al., 2009) and quality of organic matter, and decrease soil's capacity to sequester carbon (Lal, 2002; Northup et al., 2005; Savadogo et al., 2007; Klumpp et al., 2009). Research has shown that soil nutrient depletion reduces the primary production of rangelands (Girmay et al., 2008) which in turn affect their carrying capacity.

Effects of livestock grazing management systems on soil quality are poorly understood. Kgosikoma (2011) showed that livestock grazing management systems do not affect soil properties in savanna ecosystems differently. The study observed that soil texture, bulk density and $\mathrm{pH}$ did not differ between management systems despite differences in grazing intensities, though significant differences may occur occasionally between and within the study sites. Another comparative study conducted by Tefera et al. (2007) found no significant effect of livestock grazing management on soil texture, bulk density and $\mathrm{pH}$. Warren et al. (1986) found no relationship between soil bulk density and livestock stocking rates, which is in agreement with Kgosikoma (2011). A study conducted in South Africa also found no significant differences in soil chemical properties (for example, $\mathrm{pH}$ ) between grazed communal land and ungrazed land (Moussa et al., 2008). The results of these studies could suggest that livestock management 
systems do not have significant effect on soil properties especially in sandy regions. In contrast, other studies have shown that livestock grazing management systems affect soil pH (Geissen et al., 2009). The differences between these studies could probably be attributed to differences in environmental conditions such as rainfall and soil or management practices.

\section{EFFECTS OF LIVESTOCK GRAZING MANAGEMENT SYSTEMS ON HERBACEOUS VEGETATION}

Savannas in Africa are largely exploited through livestock grazing (Scholes and Archer, 1997; Bilotta et al., 2007), and the grazing intensity (removal of plant biomass by livestock) influence their sustainability (Mphinyane et al., 2008). Most grasses in savanna ecosystems are fairly tolerant to grazing, however, prolonged intense grazing eventually lead to shift in species composition (Skarpe, 1992) and reduction in grass biomass especially when soil nutrients are depleted (van Auken, 2009). Overgrazing affect the botanical composition and species diversity by depressing the vigour and presence of dominant species, which then enables colonization by less competitive, but grazing tolerant plant species (Sternberg et al., 2000). Selective grazing of palatable herbaceous plants by livestock enhances the growth of annuals and unpalatable herbaceous plants as well as woody plants (Skarpe, 1992) resulting in the decline of palatable species (Fensham et al., 2010). Overgrazed rangelands are normally dominated by Increaser II species such as Aristida congesta (Trollope et al., 1989) which are indicators of poor rangeland conditions (Fatunbi and Dube, 2008), while Increaser I species dominate undergrazed rangelands or selectively utilised rangelands (Trollope, 1990; du Plessis et al., 1998).

Tefera et al., (2007) observed a higher density of palatable herbaceous plant in ranches than in communal grazed rangelands in Ethiopia. In contrast, Kgosikoma (2011) found no significant differences in palatable herbaceous plant cover between communal grazing land and ranches at two different sites in Botswana, which was supported by other studies in other African savannas (Parsons et al., 1997; Tefera et al., 2008b). This could suggest that rangeland vegetation does not always respond in a linear way to grazing intensity (Sasaki et al., 2010), partly because local environmental conditions such as high rainfall and soil fertility regulate the plants' ability to cope with grazing pressures. However, herbaceous biomass appears to be more responsive to differences in grazing intensities between communal grazing land and ranches. Ranches exhibited a higher herbaceous biomass than the communal grazing land at most sites, which could be due to the higher grazing intensities of the communal grazing lands compared with ranches. Kgosikoma (2011). Sternberg et al. (2000) and Mphinyane et al. (2008) have also demonstrated that the biomass of herbaceous plants is highly responsive to grazing pressures.

\section{EFFECTS OF LIVESTOCK GRAZING MANAGEMENT SYSTEMS ON BUSH ENCROACHMENT}

Woody plant encroachment has been widespread in grasslands and savanna ecosystems worldwide (Archer et al., 2001): Bush encroachment is an important indicator of land degradation (van Vegten, 1984; van Auken, 2009) which has become a global concern (Moleele and Perkins, 1998; Moleele et al., 2002; Sankaran, 2009). Woody plant encroachment into grassland-dominated savannas has contributed to a decrease in the productivity of rangelands (Wiegnand et al., 2005; Douglass et al., 2011), and jeopardizes biodiversity in grasslands, which threatens the sustainability of pastoral, subsistence and commercial livestock grazing (Rappole et al., 1986; Noble, 1997). Some savanna landscapes are completely encroached by woody species, while in others savanna areas the process is in progress (Archer et al., 2001). Factors that contribute to bush encroachment are poorly understood. However, overgrazing (Moleele and Perkins, 1998), anthropogenic reductions in fire regimes (Heinl et al., 2008; Lehmann et al., 2008), frequent droughts (Cole and Brown, 1976; Scholes and Archer, 1997; Smith and Smith, 2001), and climate change (Fensham et al., 2005) are suspected to facilitate the process.

The increase in bushy vegetation in rangelands threatens livestock production in the savannas because encroaching woody species supress palatable grasses and herbs (Scholes and Archer, 1997) through competition for soil moisture and nutrients. However, encroaching leguminous woody plants such as Acacia mellifera may enrich nutrient poor sandy soils in dry savannas through nitrogen fixation (Hagos and Smit, 2005). Research has shown that soils under the canopy of tree species such as $A$. mellifera have higher levels of nitrogen, organic matter and calcium than soils distant to trees (Hagos and Smit, 2005). Some woody plants are also an important fodder resource especially during dry periods (Moleele, 1998). Therefore, a management aim of bush encroached rangelands could be selective thinning of woody vegetation to reduce the grass-tree competition, whilst retaining the beneficial effects of soil enrichment from leguminous tree and shrub species (Hagos and Smit, 2005).

Bush encroachment is an environmental problem in both ranches and communal grazing land despite the difference in grazing intensity between the two grazing management systems (Oba et al., 2000; Kgosikoma et al., 2012). Meanwhile, Wigley et al. (2009) reported that bush encroachment was a slow process in communal grazing lands than ranches due to high utilization rate of woody plants for firewood by the community. High grazing pressure can also reduce fuel loads through consumption and compaction and consequently prevent 
fire ignition (Douglass et al., 2011). In the absence of fire, bush encroachment may occur (van Langevelde et al., 2003; Sharp and Whittaker, 2003; Savadogo et al., 2007) which decreases rangeland's productivity.

\section{SUSTAINABILITY OF SAVANNA ECOSYSTEMS}

The current grazing policies in southern Africa (for example, TGLP of Botswana) were based on the assumptions that ranches would promote sustainable land use and conserve rangeland resources. However, current evidence suggests that rangeland degradation is occurring in both communal and ranching lands (Vanderpost et al., 2011). This had led to others arguing that the current grazing policies had failed to address the land degradation problem and had instead exacerbated it (Rohde et al., 2006). In addition, the communal grazing land which supports the large population of livestock continues to shrink in size as more land is demarcated into ranches (Boone, 2005). Subsequently, grazing pressures have intensified in communal grazing land (Bennett et al., 2010) especially since owners of private ranches continue to use communal grazing land in addition to their ranches (Tsimako, 1991). Considering the limited land currently available for grazing by pastoral communities (Bennett et al., 2010), the existing policies need thorough revision and dual grazing rights to the farmers allocated ranches should be eliminated. This would address the current inequity of land distribution, which could ultimately threaten the sustainability of the entire savanna ecosystem (Eriksen and Watson, 2009a).

Sustainable agro-ecosystem management depend on understanding the effects of different land use and environmental factors on ecosystems dynamics (Wallgren et al., 2009). Savanna ecosystems are complex and therefore management policies should rely on researchbased understanding of whole ecosystems. Given that long term ecological data is often missing, the local pastoral community could provide the long term perspective on changes in savanna ecosystem. The social, ecological and economic factors need to be taken into account and participatory management involving pastoral communities should be considered.

\section{CONCLUSION}

The review of scientific literature shows that overgrazing and prolonged poorly managed rangelands led to removal of desirable plant species, decrease water infiltration into soil, increase soil erosion, reduce soil nutrients and alter the plant community composition to a less desirable state. These changes compromise both the short and long-term productivity of rangelands in savanna ecosystems. Grazing policies adopted by countries in arid zones, particularly those in Africa have failed to reduce land degradation because they were based on wrong assumptions or models (Abel, 1997). Most of these policies need to be revised embracing indigenous knowledge systems, if rangeland resources in the savannas are to be used sustainably to benefit the future generation.

\section{REFERENCES}

Abel N (1997). Mis-measurement of the productivity and sustainability of African communal rangelands: $A$ case study and some principles from Botswana. Ecol. Econ. 23:113-133.

Abdel-Magid AH, Trlica MJ, Hart RH (1987). Soil and vegetation responses to simulated trampling, J. Range Manage. 40(4):303-306.

Abule E, Smit GN, Snyman HA (2005). The influence of woody plants and livestock grazing on grass species composition, yield and soil nutrients in the Middle Awash Valley of Ethiopia. J. Arid. Environ. 60:343-358.

Asner GP, Elmore AJ, Olander LP, Martin RE, Harris AT (2004). Grazing systems, ecosystem response, and global change. Ann. Rev. Environ. Resour. 29:261-299.

Archer S, Boutton TW, Hibbard KA (2001). Tree in grasslands: biogeochemical consequences of woody plant expansion. In: Schulze E-D, Harrison SP, Heimann M, Holland EA, Lloyd J, Prentice IC, Schimel D (Eds.). Global Biogeochemical Cycles in the Climate Systems. Academic Press, San Diego, pp. 115-137.

Bari F, Wood MK, Murray L (1995). Livestock grazing impacts on interill ersoin in Pakistan. J. Range Manage. 48(3):251-257.

Beeskow AM, Elissalde NO, Rostagno CM (1995). Ecosystem changes associated with grazing intensity on the Punta Ninfas rangelands of Patagonia, Argentina. J. Range Manage. 48(6):517-522.

Belsky AJ, Blumenthal DM (1997). Effects of livestock grazing on stand dynamics and soil in upland forest of the interior west. Conserv. Biol. 11(2):315-327.

Bennett J, Ainslie A, Davis J (2010). Fenced in: Common property struggles in the management of communal rangelands in central Eastern Cape Province, South Africa. Land Use Pol. 27:340-350.

Bilotta GS, Brazier RE, Haygarth PM, Donald LS (2007). The impacts of grazing animals on the quality of soils, vegetation, and surface waters in intensively managed grasslands. Adv. Agron. Academic Press, pp. 237-280.

Bohn CC, Buckhouse JC (1985). Some responses of riparian soils to grazing management in northeastern Oregon. J. Range Manage. 38(4):378-381.

Boone RB (2005). Quantifying changes in vegetation in shrinking grazing areas in Africa. Conse\& Soc 3.

Botswana Goverment (1975). National Policy on Tribal Grazing Land. Government printer, Gaborone, Botswana.

Brandy NC, Weil RR (2007). The Nature and Properties of Soils, 14th Edition. Prentice Hall, New York, p. 980.

Cole MM, Brown RC (1976). The Vegetation of the Ghanzi Area of Western Botswana. J. Biogeogr. 3:169-196.

Dahdough-Guebas F, Kairo JG, Jayatissa LP, Cannicci S, Koedam N (2002). An ordination study to view vegetation structure dynamics in disturbed and undisturbed mangrove forests in Kenya and Sri Lanka. Plant Ecol. 161:123-135.

Dahlberg AC ( 2000) Vegetation diversity and change in relation to land use, soil and rainfall - A case study from North-East District, Botswana. J. Arid Environ. 44:19-40.

Darkoh MBK (2009). An overview of environmental issues in Southern Africa. Afr. J. Ecol. 47:93-98.

Dougill AJ, Thomas DSG, Heathwaite AL (1999). Environmental Change in the Kalahari: Integrated Land Degradation Studies for Non equilibrium Dryland Environments. Ann. Assoc. Am. Geogr. 89:420442.

Douglass LL, Possingham HP, Carwardine J, Klein CJ, Roxburgh SH, Russell-Smith J, Wilson KA (2011). The effect of carbon credits on savanna land management and priorities for biodiversity conservation. Plos ONE 6(9):e23843.doi:10.131/journal.prone. 0023843. 
du Plessis WP, Bredenkamp GJ, Trollope WSW (1998). Development of a technique for assessing veld condition in Etosha National Park, Namibia, using key herbaceous species. Koedoe 41:19-29.

Du Toit GV, Synaman HA, Malan PJ (2009). Physical impact of grazing by sheep on soil properties in the Nama Karoo subshrub/grassland of South Africa. J. Arid Environ. 73:804-810.

Ellis JE, Swift DM (1988). Stability of African Pastoral Ecosystems: Alternate Paradigms and Implications for Development. J. Range Manage. 41:450-459.

Eriksen SEH, Watson HK (2009a). The dynamic context of southern African savannas: investigating emerging threats and opportunities to sustainability. Environ. Sci. Pol. 12:5-22.

Eriksen SH, Watson HK (2009b). The sustainability of southern African savannas. Environ. Sci, Pol. 12:1-4.

Fatunbi AO, Dube $S$ (2008). Land degradation in a game reserve in Eastern Cape of South Africa: Soil properties and vegetation cover. Sci. Res. Essays 3:111-119.

Fensham RJ, Fairfax RJ, Dwyer JM (2010). Vegetation responses to the first 20 years of cattle grazing in an Australian desert. Ecology. 91:681-692.

Fleischer TL (1994). Ecological costs of livestock grazing in western North America. Cons. Biol. 8(3):629-644.

Geissen V, Sánchez-Hernández R, Kampichler C, Ramos-Reyes R, Sepulveda-Lozada A, Ochoa-Goana S, de Jong BHJ, Huerta-Lwanga E, Hernández-Daumas S (2009). Effects of land-use change on some properties of tropical soils - An example from Southeast Mexico. Geoderma 151:87-97.

Groffman PM, Pouyat RV, Cadenasso ML, Zipperer WC, Szlavecz K, Yesilonis ID, Band LE, Brush GS (2007). Land use context and natural soil controls on plant community composition and soil nitrogen and carbon dynamics in urban and rural forests. For. Ecol. Manag. 246:296-297.

Hagos MG, Smit GN (2005). Soil enrichment by Acacia mellifera subsp detinens on nutrient poor sandy soil in a semi-arid southern African savanna. J. Arid. Environ. 61:47-59.

Heinl M, Sliva J, Tacheba B, Murray-Hudson M (2008). The relevance of fire frequency for the floodplain vegetation of the Okavango Delta, Botswana. Afr. J. Ecol. 46:350-358.

Hendricks HH, Bond WJ, Midgley JJ, Novellie PA (2007). Biodiversity conservation and pastoralism--reducing herd size in a communal livestock production system in Richtersveld National Park. J. Arid Environ. 70:718-727.

Herlocker DJ (1999). Rangeland Ecology and Resource Development in Eastern Africa. Deutsche Gesellschaft für Technische Zusammenarbeit (GTZ), Nairobi, Kenya. p.393.

Hopmans P, Bauhus J, Khanna P, Weston C (2005). Carbon and nitrogen in forest soils: Potential indicators for sustainable management of eucalypt forests in south-eastern Australia. For. Ecol. Manag. 220:75-87.

Ingram LJ, Stahl PD, Schuman GE, Buyer JS, Vance GF, Ganjegunte GK, Welker JM, Derner JD (2008). Grazing impacts on soil carbon and microbial communities in a mixed-grass ecosystem. Soil Sci. Am. J. 72(4):939-948.

Kauffman JB, Krueger WC (1984). Livestock impacts on riparian ecosystems and streamside management implications: A review. J. Range Manage. 37(5):430-438.

Kgosikoma OE (2011). Understanding the savanna dynamics in relation to rangeland management systems and environmental conditions in semi-arid Botswana. PhD thesis. Univesity of Edinburgh.

Kgosikoma OE, Harvie BA, Mojeremane W (2012). Bush encroachment in relation to rangeland management systems and environmental conditions in Kalahari ecosystem of Botswana. Afr. J. Agric. Res. 7:2312-2319.

Kioko J, Kiringe JW, Seno SO (2012). Impacts of livestock grazing on a savanna grassland in Kenya. J. Arid Land 4(1):29-35.

Klumpp K, Fontaine S, Attard E, Le Roux X, Gleixner G, Sousssana JF (2009). Grazing triggers soil carbon loss by altering plant roots and their control on soil microbial community. J. Ecol. 97:876-885.

Lal R (2002). Soil carbon dynamics in cropland and rangeland. Environ. Pollution 116:353-362.

Liebig MA, Gross JR, Kronberg SL, Hanson JD, Frank AB, Phillips RL (2006). Soil response to long-term grazing in the northern Great
Plains of North America. Agric. Ecosyst. Environ. 115:270-276.

Lehmann CER, Prior LD, Williams RJ, Bowman DMJS (2008). Spatiotemporal trends in tree cover of a tropical mesic savanna are driven by landscape disturbance. J Appl. Ecol. 45:1304-1311.

Masike S, Urich P (2008). Vulnerability of traditional beef sector to drought and the challenges of climate change: The case of Kgatleng District, Botswana. J. Geogr Reg. Plan. 1:012-018.

Mohammed AS, Bekele T (2010). Forage production and plant diversity in two managed rangelands in the Main Ethiopian Rift. Afr. J. Ecol. 48:13-20.

Moleele NM (1998). Encroacher woody plant browse as feed for cattle. Cattle diet composition for three seasons at Olifants Drift, south-east Botswana. J. Arid Environ. 40:255-268.

Moleele NM, Perkins JS (1998). Encroaching woody plant species and boreholes: is cattle density the main driving factor in the Olifants Drift communal grazing lands, south-eastern Botswana? J. Arid Environ. 40:245-253.

Moleele NM, Ringrose S, Matheson W, Vanderpost C (2002). More woody plants?: The status of bush encroachment in Botswana's grazing areas. J. Environ. Manag. 64:3-11.

Moussa AS, Van Rensburg L, Kellner K, Bationo A (2008). Soil indicators of rangeland degradation in a semi-arid communal district in South Africa. Fut Drylands, pp. 383-393.

Mphinyane WN, Tacheba G, Mangope S, Makore J (2008). Influence of stocking rate on herbage production, steers livemass gain and carcass price on semi-arid sweet bushveld in Southeren Botswana. Afr. J. Agric. Res. 3:084-090.

Muhumuza M, Byarugaba D (2009). Impact of land use on the ecology of uncultivated plant species in the Rwenzori mountain range, mid western Uganda. Afr. J. Ecol. 47:614-621.

Neff JC, Reynolds RL, Belnap J, Lamothe P (2005). Multi-decadal of grazing on soil physical and biochemical properties in southeast Utah. Ecol. Appl. 15(1):87-95.

Nobble JC (1997). The delicate and noxious scrub: Studies on native tree and shrub proliferation in semi-arid woodlands of Australia. CSIRO Division of Wildlife and Ecology, Canberra.

Northup BK, Brown JR, Ash AJ (2005). Grazing impacts on spatial distribution of soil and herbaceous characteristics in an Australian tropical woodland. Agrofor. Syst. 65:137-150.

Oba G, Post E, Syverstssen PO, Stenseth NC (2000). Bush cover and range condition assessments in relation to landscape and grazing in southern Ethiopia. Landsc. Ecol. 15(6):535-546.

O' Connor TG (2005). Influence of land use on plant community composition and diversity in Highland Sourveld grassland in the southern Drakensberg, South Africa. J. Appl. Ecol. 42:975-988.

Owen-Smith N (1999). The annual factor in veld management: Implications of selective patterns of grazing. In:Taintan ND (eds).Veld Management in South Africa. University of Natal Press, Pietrmaritzburg, pp. 129-130.

Parsons DAB, Shackleton CM, Scholes RJ (1997). Changes in herbaceous layer condition under contrasting land use systems in the semi-arid lowveld, South Africa. J. Arid Environ. 37:319-329.

Pluhar JJ, Knight RW, Heitschmidt RK (1987). Infiltration rates and sediments production as influenced by grazing systems in the Texas rolling plains. J. Range Manage. 40(3):240-243.

Popolizio CA, Coetz H, Chapman PL (1994). Short-term response of riparian vegetation to 4 grazing treatments. J. Range Manage. 47(1):48-53.

Rappole JH, Russell CE, Fulbright TE (1986). Anthropogenic pressure and impacts on marginal, neotropical, semiarid ecosystems: The case of south Texas. Sci. Total Environ. 55:91-99.

Reed MS, Dougill AJ, Baker TR (2008). Participatory indicator development: What can ecologists and local communities learn from each other? Ecol. Appl. 18:1253-1269.

Roberstson E (1996). Impacts of livestock grazing on soils and recommendations of management. $<$ http://www.cnps.org/cnps/archive/letters/soils.pdf>.

Rohde RF, Moleele NM, Mphale M, Allsopp N, Chanda R, Hoffman MT, Magole L, Young E (2006). Dynamics of grazing policy and practice: Environmental and social impacts in three communal areas of southern Africa. Environ. Sci. Pol. 9:302-316.

Roose E, Barthes B (2001). Organic matter management for soil 
conservation and productivity restoration in Africa: A contribution from Francophone research. Nutr. Cycl. Agroecosyst. 61:159-170.

Sankaran M (2009). Diversity patterns in savanna grassland communities: Implications for conservation strategies in a biodiversity hotspot. Biod. Conser. 18:1099-1115.

Sankaran M, Hanan NP, Scholes RJ, Ratnam J, Augustine DJ, Cade BS, Gignoux J, Higgins SI, Le Roux X, Ludwig F, Ardo J, Banyikwa F, Bronn A, Bucini G, Caylor KK, Coughenour MB, Diouf A, Ekaya W, Feral CJ, February EC, Frost PGH, Hiernaux P, Hrabar H, Metzger $\mathrm{KL}$, Prins HHT, Ringrose S, Sea W, Tews J, Worden J, Zambatis N (2005). Determinants of woody cover in African savannas. Nature, 438:846-849.

Sasaki T, Okubo S, Okayasu T, Jamsran U, Ohkuro T, Takeuchi K (2010). Indicator species and functional groups as predictors of proximity to ecological thresholds in Mongolian rangelands. Plant Ecol. pp. 1-16.

Savadogo P, Sawadogo L, Tiveau D (2007). Effects of grazing intensity and prescribed fire on soil physical and hydrological properties and pasture yield in the savanna woodlands of Burkina Faso. Agric. Ecosyst. Environ. 118:80-92.

Scholes RJ (1990). The Influence of Soil Fertility on the Ecology of Southern African Dry Savannas. J. Biogeogr. 17:415-419.

Scholes RJ, Archer SR (1997). Tree-grass interactions in savannas. Ann. Rev. Ecol. Syst. 28:517-544.

Sharp BR, Whittaker RJ (2003). The irreversible cattle-driven transformation of a seasonally flooded Australian savanna. J. Biogeogr. 30:783-802.

Skarpe C (1992). Dynamics of savanna ecosystems. J. Veget. Sci. 3(3):293-300.

Smet M, Ward D (2005). A comparison of the effects of different rangeland management systems on plant species composition, diversity and vegetation structure in a semi-arid savanna. Afri. J. Rang. For. Sci. 22:59-71.

Smith RL, Smith TM (2001). Ecology \& Field Biology. Benjamin Cummings, New York.

Snyman HA, du Preez CC (2005). Rangeland degradation in a semiarid South Africa - II: influence on soil quality. J. Arid Environ. 60:483507.

Sternberg M, Gutman M, Perevolotsky A, Ungar ED, Kigel J (2000). Vegetation response to grazing management in a Mediterranean herbaceous community: a functional group approach. J. Appl. Ecol. 37:224-237.

Steffens M, Kölbl A, Totsche KU, Kögel-Knsbner I (2008). Grazing effects on soil chemical and physical properties in a semi-arid steppe of Inner Mangolia (P. R. China). Geordoma 143:63-72.

Stephenson GR, Veigel A (1987). Recovery of compacted soil on pasture used for winter cattle feeding. J. Range Manage. 40(1):4648.

Tefera SB (2011). Seed dynamics in relation to land degradation management and soil types in the semi-arid savannas of Swaziland. Afr. J. Agric. Res. 6(11):2494-5505.

Tefera S, Dlamini BJ, Dlamini AM (2010). Changes in soil characteristics and grass layer condition in relation to land management systems in the semi-arid savannas of Swaziland. J. Arid Environ. 74:675-684.

Tefera S, Dlamini BJ, Dlamini AM, Mlambo V (2008b). Current range condition in relation to land management systems in semi-arid savannas of Swaziland. Afr. J. Ecol. 46:158-167.

Tefera S, Snyman HA, Smit GN (2007). Rangeland dynamics in southern Ethiopia: (1) Botanical composition of grasses and soil characteristics in relation to land-use and distance from water in semi-arid Borana rangelands. J. Environ. Manag. 85:429-442.
Thomas DSG, Sporton D (1997). Understanding the dynamics of social and environmental variability: The impacts of structural land use change on the environment and peoples of the Kalahari, Botswana. Appl. Geogr. 17:11-27.

Thurow TL, Blackburn WH, Taylor Jr, CA (1986). Hydrologic characteristsics of vegetation types as affected by livestock grazing systems, Edwards Plateau, Texas. J. Range Manage. 39(6):505-508.

Trollope WSW, Potgieter ALF, Zambatis N (1989). Assessing veld condition in the Kruger National Park South Africa using key grass species. Koedoe 32:67-94.

Tsimako B (1991). The Tribal Grazing Land Policy (TGLP) Ranches Performance to Date. Agricultural Planning and Statistics, Gaborone.

van Auken OW (2009). Causes and consequences of woody plant encroachment into western North American grasslands. J. Environ. Manag. 90:2931-2942.

van Langevelde F, van de Vijver C, Kumar L, van de Koppel J, de Ridder N, van Andel J, Skidmore AK, Hearne JW, Stroosnijder L, Bond WJ, Prins HHT, Rietkerk M (2003). Effects of fire and herbivory on the stability of savanna ecosystems. Ecology 84:337-350.

van der Heijden GMF, Phillips OL (2009). Environmental effects on Neotropical liana species richness. J. Biogeogr. 36:1561-1572.

Vanderpost C, Ringrose S, Matheson W, Arntzen J (2011). Satellite based long-term assessment of rangeland condition in semi-arid areas: An example from Botswana. J. Arid Environ. 75:383-389.

van Vegten JA (1984). Thornbush Invasion in a Savanna Ecosystem in Eastern Botswana. Vegetatio, 56:3-7.

Vavra M, Parks CG, Wisdom MJ (2007). Biodiversity, exotic plant species, and herbivory: The good, the bad, and the ungulate. For. Ecol. Manage. 246:66-72.

Vetter S (2005) Rangelands at equilibrium and non-equilibrium: Recent developments in the debate. J. Arid Environ. 62:321-341.

Walker SM, Desanker PV (2004). The impact of land use on soil carbon in miombo woodland of Malawi. For. Ecol. Manage. 203:345-360.

Wallgren M, Skarpe C, Bergström R, Danell K, Bergström A, Jakobsson $\mathrm{T}$, Karlsson K, Strand T (2009). Influence of land use on the abundance of wildlife and livestock in the Kalahari, Botswana. J. Arid Environ. 73:314-321.

Warren SD, Nevill MB, Blackburn WH, Garza NE (1986). Soil response to trampling under intensive rotation grazing. Soil Sci. Soc. Am. J. 50(5):1336-1341.

Weimer B (1977). The Tribal Grazing Land Policy in the Context of Botswana's Rural Development Policy - A Documentary overview. In: Weimer, B. (Ed.), A policy for rural development: the case of Botswana's national policy on tribal grazing land. National Institute for Research in Development and African studies, Gaborone.

Westoby M, Walker B, Noymeir I (1989). Opportunistic Management for Rangelands Not at Equilibrium. J. Range Manage. 42:266-274.

Wiegand K, David W, David S (2005). Multi-scale patterns and bush encroachment in an arid savanna with a shallow soil layer. J. Veget. Sci. 16:311-320.

Wigley BJ, Bond WJ, Hoffman MT (2009). Bush encroachment under three contrasting land-use practices in a mesic South African savanna. Afr. J. Ecol. 47:62-70.

Wigley BJ, Bond WJ, Hoffman MT (2010). Thicket expansion in a South African savanna under divergent land use: Local vs. global drivers? Glob. Chang. Biol. 16:964-976. 